\title{
Inhibition of T Cell Apoptosis in the Rheumatoid Synovium
}

\author{
Mike Salmon, ${ }^{*}$ Dagmar Scheel-Toellner, ${ }^{*}$ Aarnoud P. Huissoon, ${ }^{*}$ Darrell Pilling, ${ }^{*}$ Nasrin Shamsadeen, ${ }^{*}$ Helena Hyde, ${ }^{\ddagger}$ \\ Arnaud Dupuy D’Angeac, ${ }^{\S}$ Paul A. Bacon, ${ }^{*}$ Paul Emery, ${ }^{\star}$ and Arne N. Akbar ${ }^{\ddagger}$ \\ *Department of Rheumatology, The University of Birmingham, Birmingham, United Kingdom; ${ }^{*}$ Department of Clinical Immunology, \\ The Royal Free Hospital, London, United Kingdom; and ${ }^{\S}$ Laboratory of Molecular Virology, CNRS 1487, Montpellier, France
}

\begin{abstract}
Synovial $\mathrm{T}$ cells in rheumatoid arthritis are highly differentiated and express a phenotype suggesting susceptibility to apoptosis (CD45RB ${ }^{\text {dull }}$, CD45RO ${ }^{\text {bright }}, \mathrm{Bcl}^{\text {low }}$, Bax ${ }^{\text {high }}$, Fas $\left.^{\text {high }}\right)$. However, no evidence of $\mathrm{T}$ cell apoptosis was found in synovial fluid from any of 28 patients studied. In contrast, synovial fluid from 10 patients with crystal arthritis showed substantial levels of $T$ cell apoptosis. The failure of apoptosis was not an intrinsic property of rheumatoid synovial $T$ cells, as they showed rapid spontaneous apoptosis on removal from the joint.

Synovial T cells from rheumatoid arthritis and gout patients could be rescued from spontaneous apoptosis in vitro either by IL-2R $\gamma$ chain signaling cytokines (which upregulate Bcl-2 and Bcl- $\mathrm{x}_{\mathrm{L}}$ ) or by interaction with synovial fibroblasts (which upregulates Bcl- $\mathrm{x}_{\mathrm{L}}$ but not $\mathrm{Bcl}-2$ ). The phenotype of rheumatoid synovial $\mathrm{T}$ cells ex vivo (Bcl-2 ${ }^{\text {low }}, \mathrm{Bcl}-\mathrm{x}_{\mathrm{L}}{ }^{\text {high }}$ ) suggested a fibroblast-mediated mechanism in vivo. This was confirmed by in vitro culture of synovial $\mathrm{T}$ cells with fibroblasts which maintained the $\mathrm{Bcl}-\mathrm{x}_{\mathrm{L}}{ }^{\text {high }} \mathrm{Bcl}-2^{\text {low }}$ phenotype. Synovial $\mathrm{T}$ cells from gout patients were $\mathrm{Bcl}-2^{\text {low }} \mathrm{Bcl}-\mathrm{x}_{\mathrm{L}}{ }^{\text {low }}$ and showed clear evidence of apoptosis in vivo.

Inhibition experiments suggested that an integrin-ligand interaction incorporating the Arg-Gly-Asp motif is involved in fibroblast-mediated synovial $\mathrm{T}$ cell survival. We propose that environmental blockade of cell death resulting from interaction with stromal cells is a major factor in the persistent $T$ cell infiltration of chronically inflamed rheumatoid synovium. (J. Clin. Invest. 1997. 99:439-446.) Key words: rheumatoid arthritis • T lymphocytes $\bullet$ apoptosis $\bullet$ CD45 • inflammation
\end{abstract}

\section{Introduction}

Rheumatoid arthritis (RA) is characterized by T lymphocyte accumulation within the synovial compartment. This may result from increased migration of activated $\mathrm{T}$ cells into the joint,

Address correspondence to Mike Salmon, Department of Rheumatology, Birmingham University, Birmingham B15 2TT, United Kingdom. Phone: 44-0-121-414-6780; Mobile phone: 44-0-378-898-238; FAX: 44-0-121-414-6794; E-mail: M.Salmon@bham.ac.uk Paul Emery's current address is Rheumatology and Rehabilitation Research Unit, University of Leeds, United Kingdom.

Received for publication 4 June 1996 and accepted in revised form 20 November 1996.

J. Clin. Invest.

(C) The American Society for Clinical Investigation, Inc.

0021-9738/97/02/0439/08 \$2.00

Volume 99, Number 3, February 1997, 439-446 proliferation in situ, or inhibition of $\mathrm{T}$ cell death, leading to persistence of the infiltrating cells (1). About 5-20\% of these cells are activated, but they appear to be dysfunctional. T cells isolated from synovial tissue and fluid respond poorly to stimulation with mitogen or antigens. In this study we have tested the hypothesis that the synovial microenvironment favors persistent $\mathrm{T}$ cell infiltration by actively inhibiting $\mathrm{T}$ cell apoptosis.

Primed and unprimed $T$ cells can be distinguished by their respective expression of the CD45RO and CD45RA isoforms of the leukocyte common antigen (2-4). Furthermore, highly differentiated T cells within the CD45RO+ pool can be distinguished from recently primed cells by their relative expression of a third leukocyte common antigen isoform: CD45RB $(5,6)$. Recently primed cells are CD45RB ${ }^{\text {bright }} \mathrm{CD} 45 \mathrm{RO}^{\text {dull }}$, while highly differentiated cells are $C D 45 R^{\text {dull }} C D 45 R^{\text {bright }}$. T cells found in the rheumatoid synovium are almost exclusively CD45RB ${ }^{\text {dull }}$ highly differentiated cells $(7,8)$. CD45RB ${ }^{\text {dull }}$ cells isolated from peripheral blood show marked susceptibility to apoptosis. These cells synthesize very little IL-2, a cytokine which is a potent inhibitor of $\mathrm{T}$ cell apoptosis $(5,9,10)$. The highly differentiated CD45RB ${ }^{\text {dull }}$ character of synovial $\mathrm{T}$ cells would suggest that they should also be susceptible to apoptosis, a process that would contribute towards resolution of inflammatory lesions. However, the failure of synovial $\mathrm{T}$ cells to die, even though they exhibit characteristics of an apoptosisprone population, may lead to their persistence within this compartment and a consequent failure to resolve the synovial inflammation.

The apoptosis of T cells can be induced actively by ligation of molecules such as Fas/Apo-1 (CD95) $(11,12)$ or passively, by inadequate levels of stimulatory cytokines $(9,10)$. In T cells any member of a class of cytokines, including IL-2, IL-4, IL-7, IL-13, and IL-15, that uses a shared receptor signaling component that forms the $\gamma$ chain of the IL-2 receptor can inhibit apoptosis induced through cytokine withdrawal $(13,14)$. One way in which these cytokines prevent apoptosis is by upregulating expression of genes, including $\mathrm{Bcl}-2$ and the large splice variant of $B c l-x$, that code for antiapoptotic regulatory proteins relative to $B a x$, a homologue of $B c l-2$ that promotes apoptosis $(13,15,16)$. It is of interest that high levels of IL-15 have been reported in the rheumatoid synovium (17), suggesting a possible non-T cell-dependent mechanism of rescue for activated $\mathrm{T}$ cells in situ, as IL-15 is produced by macrophages and possibly stromal cells, but not apparently by T cells (14).

Cytokine-deprived T cells can also be rescued from apoptosis by interaction with stromal cells such as fibroblasts $(10$, 18) though other cells such as endothelial cells are equally effective (19). Direct cell contact is not necessary, because supernatants from fibroblast culture are effective for $\mathrm{T}$ cell rescue $(18,19)$. Interestingly, stromal cells prevent $\mathrm{T}$ cell apoptosis without increasing expression of $\mathrm{Bcl}-2$ or inducing proliferation, suggesting a quite distinct mechanism to that mediated by 
IL-2 receptor $\gamma$ chain cytokines $(13,19)$. The pannus tissue associated with rheumatoid synovitis contains a high density of proliferating fibroblasts (20) and fibroblasts from these lesions are the most effective source for inhibiting $\mathrm{T}$ cell apoptosis (18). This suggested that the synovial microenvironment has the capacity to prevent $\mathrm{T}$ cell apoptosis.

We have found that highly differentiated synovial $\mathrm{T}$ cells are actively inhibited from undergoing apoptosis in the rheumatoid synovial microenvironment. Removal of $\mathrm{T}$ cells from the joint leads to rapid apoptosis which can be inhibited in vitro by addition of IL-2 and/or IL-15 and also by fibroblast coculture. However, the phenotype of synovial T cells suggests that they probably survive as a result of fibroblast interactions. These observations indicate that the synovial compartment in RA is a potent antiapoptotic environment and that inflammation in this disease may persist as a result of inappropriate signals for the survival of highly differentiated $\mathrm{T}$ cells.

\section{Methods}

Patients and cell separation. Paired samples of peripheral venous blood and synovial fluid were collected into preservative-free heparin, from patients who fulfilled the 1987 ACR criteria for RA (21), and from patients with acute uric acid-induced crystal arthritis. All patients had active synovitis.

Synovial fluid samples were treated with $10 \mathrm{U} / \mathrm{ml}$ hyaluronidase for $30 \mathrm{~min}$ at $37^{\circ} \mathrm{C}$. For the analysis of total leukocytes by flow cytometry, erythrocytes were removed using erythrolyse (Serotec, Oxford, United Kingdom). No other fractionation was performed. T cell subsets were isolated for agarose gel electrophoresis by positive selection using anti-CD4 and anti-CD8 coated magnetic beads (Dynal, New Ferry, Wirral, United Kingdom). For culture experiments, peripheral blood and synovial fluid lymphocytes were isolated by Ficoll-Paque centrifugation followed by adherence depletion of monocytes. T cell subsets were isolated by negative selection using immunomagnetic beads (Dynal) with a cocktail of monoclonal antibodies designed to deplete CD14, CD16, and CD19 and either CD4+ or CD8+ cells. $\mathrm{CD} 45 \mathrm{RO}+$ cells were enriched by the addition of anti-CD45RA as described previously $(5,10,22)$. These procedures routinely achieved $>95 \%$ purity.

Surface and intracellular immunofluorescence detection. Analysis of surface and intracellular molecules was performed using threecolor immunofluorescence with EPICS XL and ELITE flow cytometers (Coulter Corp., Hialeah, FL). The optimum concentration of each reagent was determined by preliminary titration. FITC, phycoerythrin, RED 670 (GIBCO-BRL, Paisley, United Kingdom), and propidium iodide were excited at $488 \mathrm{~nm}$ using an argon laser. Conjugated irrelevant antibodies of each isotype (Dako, High Wycombe, United Kingdom) were used to establish the specificity of staining. For intracellular labeling, isolated cells were first surface labeled with phycoerythrin-conjugated antibodies specific for CD4 (Leu 3a; Becton Dickinson, Mountain View, CA) or CD8 (RFT8; The Royal Free Hospital, London) and biotin-conjugated antibodies specific for isoforms of CD45 as described (5). Biotin was detected using Streptavidin-RED 670. Labeled cells were then fixed and permeabilized using PermeaFix (Ortho Diagnostics, Raritan, NJ) $500 \mu \mathrm{l} / 10^{6}$ cells for $45 \mathrm{~min}$ at room temperature before incubation with specific antibodies to Bcl-2 (Dako), Bcl-x $\mathrm{L}_{\mathrm{L}}$, (Santa Cruz Biotechnologies, Santa Cruz, CA), Bax (Santa Cruz Biotechnologies), or ASP (23) (Oncogene Science, Uniondale, NJ). The polyclonal Bcl- $\mathrm{x}_{\mathrm{L}}$, Bax, and ASP-specific antibodies were detected using a secondary FITC-conjugated sheep antirabbit Ig (Binding Site, Birmingham, United Kingdom). Surface Fas expression was also detected using FITC fluorescence using anti-Fas (Upstate Biotechnologies Inc., Lake Placid, NY) in conjunction with the surface markers detailed above. Cytometer calibration was standardized using fluorospheres (Immunocheck and Standardbrite;
Coulter Corp.). Fluorescence compensation was adjusted using samples of peripheral blood mononuclear cells labeled individually with anti-CD4 antibodies conjugated to each fluorochrome. Where appropriate, samples were gated using forward and side scatter to exclude dead cells.

Detection of apoptosis. Agarose gel electrophoresis was used to detect internucleosomal cleavage fragments of DNA after apoptosis as described previously (24). CD4+ and CD8 + T cells were isolated directly for electrophoresis by positive selection with Dynabeads from crude synovial fluid, without any preliminary purification. For all other techniques of apoptosis detection, no preliminary purification was performed; $T$ cells were identified in the complex cell populations present in crude synovial fluid by CD3 labeling. This was important to avoid loss of apoptotic cells which routinely occurs during density centrifugation.

To identify fragmented DNA in single cells in conjunction with anti-CD3 labeling to discriminate T cells, a modification of the TUNEL methodology (25) was used with flow cytometry. Approximately $10^{6}$ cells per sample were labeled with either phycoerythrin-labeled antiCD3 mAb (Dako) or phycoerythrin-labeled isotype-matched control antibody. The amount of synovial fluid required was estimated from preliminary cell counts. The labeled cells were washed in PBS $(\mathrm{pH}$ 7.4) and fixed in PermeaFix solution (Ortho Diagnostics) for 45 min at room temperature. After fixation cells were washed twice in PBS containing $0.01 \%$ BSA and then in Terminal-deoxytransferase (TdT) buffer ( $0.1 \mathrm{M}$ potassium cacodylate, $\mathrm{pH}$ 7.2, $2 \mathrm{mM}$ cobalt chloride, 0.2 $\mathrm{mM}$ dithiothreitol). The cells were then resuspended in $50 \mu \mathrm{l} 1 \times \mathrm{TdT}$ buffer containing 6.25 U Terminal transferase (Boehringer Mannheim Corp., Indianapolis, IN), $2 \mu \mathrm{M}$ ATP (Pharmacia Fine Chemicals, Piscataway, NJ), $2 \mu \mathrm{M}$ digoxigenin-conjugated dUTP and incubated at $37^{\circ} \mathrm{C}$ for $30 \mathrm{~min}$. Samples were then washed twice in $0.5 \mathrm{mM}$ EDTA in PBS. Bound digoxigenin was detected with fluoresceinconjugated monoclonal anti-digoxigenin antibody (Boehringer Mannheim Corp.). The samples were analyzed using the EPICS XL cytometer. As positive controls, IL-2-deprived cells from a murine cytotoxic $\mathrm{T}$ cell line (CTLL-2) were used. Negative controls were labeled in the absence of terminal transferase.

Phosphatidylserine residues on the surface of leukocytes were detected as an index of apoptosis, by labeling with Annexin V-FITC (26) (ApopTest, Brand Applications, Maastricht, The Netherlands) and propidium iodide $(50 \mu \mathrm{g} / \mathrm{ml})$ for $10 \mathrm{~min}$ on ice. Cells were then analyzed by flow cytometry. Propidium iodide positive cells were excluded from analysis because permeable cells bind Annexin $\mathrm{V}$ to phosphatidylserine residues on the intracellular surface of the plasma membrane, which may reflect trauma rather than apoptosis.

$T$ cell stimulation and culture. $\mathrm{T}$ cells from peripheral blood and synovial fluid were cultured in RPMI 1640 (GIBCO-BRL), containing $10 \%$ human serum, glutamine $(2 \mathrm{mM})$, penicillin $(100 \mathrm{U} / \mathrm{ml})$, and streptomycin $(100 \mu \mathrm{g} / \mathrm{ml})$. T cells were stimulated with anti-CD3 (OKT-3, $100 \mathrm{ng} / \mathrm{ml}$; Ortho Diagnostics) with or without anti-CD28 (L293, $100 \mathrm{ng} / \mathrm{ml}$; Becton Dickinson) antibodies in the presence or absence of IL-2 (25 U/ml; Eurocetus, Harefield, United Kingdom). CD3 and CD28 antibodies were cross-linked with $100 \mathrm{ng} / \mathrm{ml}$ goat anti-mouse antibody (Southern Biotechnology Associates, Birmingham, AL). Cells were cultured for up to $12 \mathrm{~d}$ and viable cell counts were performed at intervals using the volume counting function of the EPICS XL cytometer. Total cell numbers were assessed by accurately resuspending the cell culture in the original volume and analyzing a defined $20-\mu l$ volume. Viable cells were identified by exclusion of propidium iodide and forward/side scatter characteristics.

Fibroblast coculture and $T$ cell rescue experiments. Fibroblast cell lines were obtained from synovial tissue of patients with RA undergoing joint replacement surgery. Briefly, synovial tissue was cut into fragments of $1 \mathrm{~mm}$ in diameter and incubated in $0.2 \%$ collagenase at $37^{\circ} \mathrm{C}$. The resulting cell suspension was washed twice and then cultured in fibroblast medium [RPMI 1640, 10\% FCS, $2 \mu \mathrm{M}$ glutamine, $100 \mathrm{U} / \mathrm{ml}$ penicillin, $100 \mu \mathrm{g} / \mathrm{ml}$ streptomycin, $1 \%$ nonessential amino acid solution (Sigma Chemical Co., St. Louis, MO), $1 \mathrm{mM}$ sodium 
pyruvate]. Nonadherent cells were removed after overnight culture. Passages 3 to 6 of the outgrowing fibroblast lines were used. For comparison, fibroblasts were also obtained from one patient with psoriatic arthritis, healthy dermal fibroblast lines, and an embryonic lung fibroblast line (a kind gift from Dr. J. Grundy, The Royal Free Hospital, London).

CD45RO positive $\mathrm{T}$ cells from peripheral blood and synovial fluid were isolated by negative selection as described above and cultured either in complete medium alone or on confluent fibroblast monolayers in 24-well plates (10). Culture supernatants from confluent fibroblast monolayers were used in place of the monolayers in cocultures (10) to test the effect of the tetrapeptides Arg-Gly-AspSer (RGDS) (1 mM) and Arg-Gly-Glu-Ser (RGES) (1 mM) on fibroblast-mediated rescue of $\mathrm{T}$ cells and for analysis of phenotype changes. The number of surviving cells was measured at intervals to determine the effect of each treatment on rate of cell death. A range of molecules was tested for their capacity to rescue synovial $\mathrm{T}$ cells in similar experiments, including: IL-2 (Eurocetus), IL-4, IL-6, IL-7, IL-15 (Peprotech, Rocky Hill, NJ), IL-10 (Genzyme Corp., Cambridge, MA), PDGF, IGF-1 (R\&D Systems, Minneapolis, MN), hyaluronic acid, and both serum and fibroblast-derived fibronectin (Sigma Chemical Co.). All cytokines were tested by direct addition to culture in a concentration range from 0.1 to $10 \mathrm{ng} / \mathrm{ml}$ (13). Fibronectin and hyaluronic acid were tested by prior binding to plates, as described previously (27) and also by direct addition to cell cultures (13). Polyclonal antibody specific for IL-15 was purchased from Peprotech.

\section{Results}

T cell apoptosis in RA synovial fluid. Preliminary morphological screening of 50 sequentially referred synovial fluid samples from rheumatoid patients failed to reveal any evidence of apoptotic $\mathrm{T}$ cells either free or engulfed by macrophages, despite clear evidence of non-T cell apoptosis (largely neutrophils) in many of these samples. To test this objectively we studied synovial fluid samples from 28 patients with RA and 10 patients with uric acid-associated crystal arthritis (gout), using a range of methods to identify apoptosis. These included agarose gel electrophoresis of unselected synovial fluid leukocytes compared with positively selected T cells, to assess DNA fragmentation, the TUNEL method of fragmentation analysis, detection of externalized phosphatidylserine using Annexin V, and labeling of ASP. All cell labeling methods (TUNEL, Annexin
$\mathrm{V}$, and ASP) were performed as double immunofluorescence analyses by flow cytometry with anti-CD3 to avoid the need for preliminary purification, which may lose apoptotic cells. The unfractionated cells showed clear evidence of apoptosis by gel electrophoresis, but this was not apparent in any T cell population from the 28 patients studied. Each of the cytometric methods for detecting apoptosis revealed substantial cell death in non-T cells but no apoptosis within $\mathrm{T}$ cells using any method in any of the rheumatoid patients $(<0.1 \%)$ (Fig. $1 a)$. Intriguingly, the 10 patients studied with acute crystal arthropathy all showed marked $\mathrm{T}$ cell apoptosis (median $14.3 \%$, range $5.8-73.5 \%$ ) (Fig. $1 b$ ). The difference between RA and gout was significant using the Mann Whitney $U$ test $(P<0.001)$.

Expression of bcl-2, Bax, Bcl-x, and Fas by synovial fluid $T$ cells in $R A$. Peripheral blood and synovial fluid mononuclear cells from eight patients with RA and four with crystal arthritis were labeled with anti-Bcl-2, Bax, Bcl- $\mathrm{x}_{\mathrm{L}}$, or Fas in conjunction with anti-CD4 and CD45RB. Peripheral blood T cells from both patient groups showed a similar distribution of these molecules to healthy individuals we have described previously (5). T cells from the synovial fluid of RA patients were a highly selected CD45RB ${ }^{\text {dull }}$ population (Fig. $2 f$ ), though all three gout patients showed a small CD45RB ${ }^{\text {bright }}$ peak (Fig. $2 p$ ). Synovial fluid T cells from both patient groups showed low Bcl-2 (Fig. 2, $a$ and $k$ ) and high Fas expression (Fig. 2, $d$ and $n$ ). Bax was indistinguishable from blood levels (Fig. 2, $c$ and $m$ ). Expression of Bcl-2 and Fas is known to be influenced by the CD45-defined differentiation status of $\mathrm{T}$ cells. To eliminate bias due to enrichment of $\mathrm{CD} 45 \mathrm{RB}^{\text {dull }}$ cells in the synovium, we compared CD45RB ${ }^{\text {dull }}$ cells in blood with the same population in synovial fluid (Fig. $2, g-j$ and $q-t$ ). It was apparent that the marked difference in Fas expression between blood and synovial cells simply reflects CD45RB ${ }^{\text {dull }}$ enrichment (Fig. 2, $d$ and $j$, and $n$ and $t$ ), but the reduced level of Bcl-2 expression was apparent even within this subset (Fig. 2, $a$ and $g$, and $k$ and $q$ ). One clear and consistent difference was observed between synovial T cells from RA and gout patients: in RA, Bcl- $\mathrm{x}_{\mathrm{L}}$ expression was indistinguishable from blood (Fig. $2 b$ ), but in all three gout patients $\mathrm{Bcl}-\mathrm{x}_{\mathrm{L}}$ expression was markedly reduced (Fig. 2 l). The low level expression of Bcl-2 and high expression of Fas by synovial $\mathrm{T}$ cells are characteristics suggesting marked susceptibility to apoptosis.

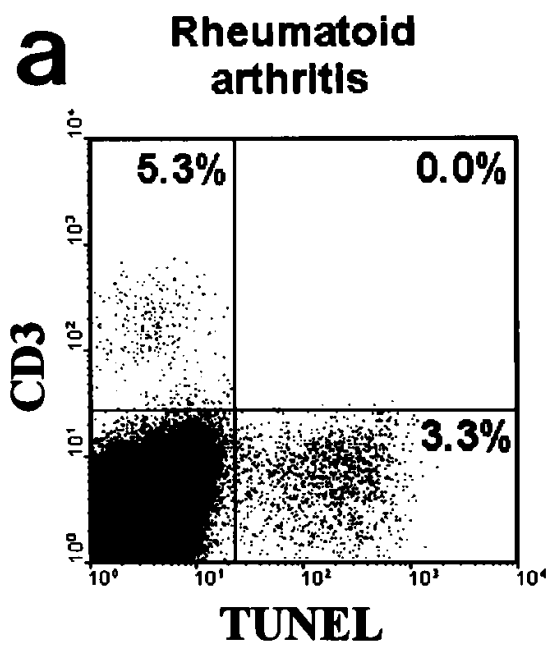

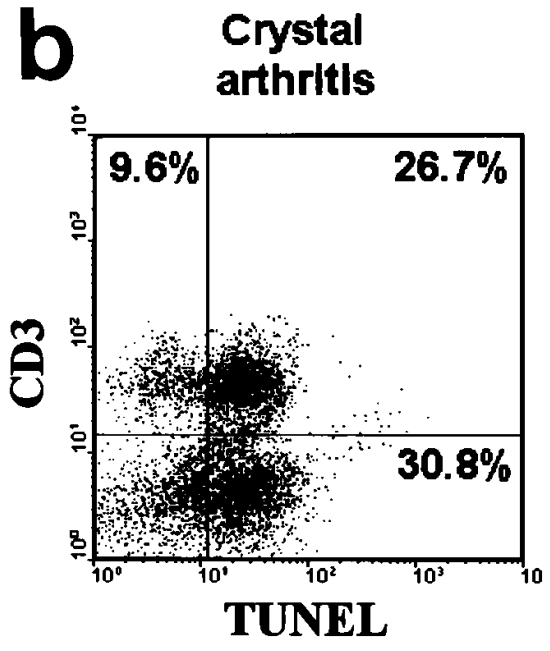

Figure 1. Analysis of apoptotic T cells by double labeling with anti-CD3 and the TUNEL method for detecting single cell DNA fragmentation. (a) RA, (b) crystal arthritis (gout). Apoptotic T cells fall into the upper right quadrant. Representative of 24 and 6 patients, respectively. 


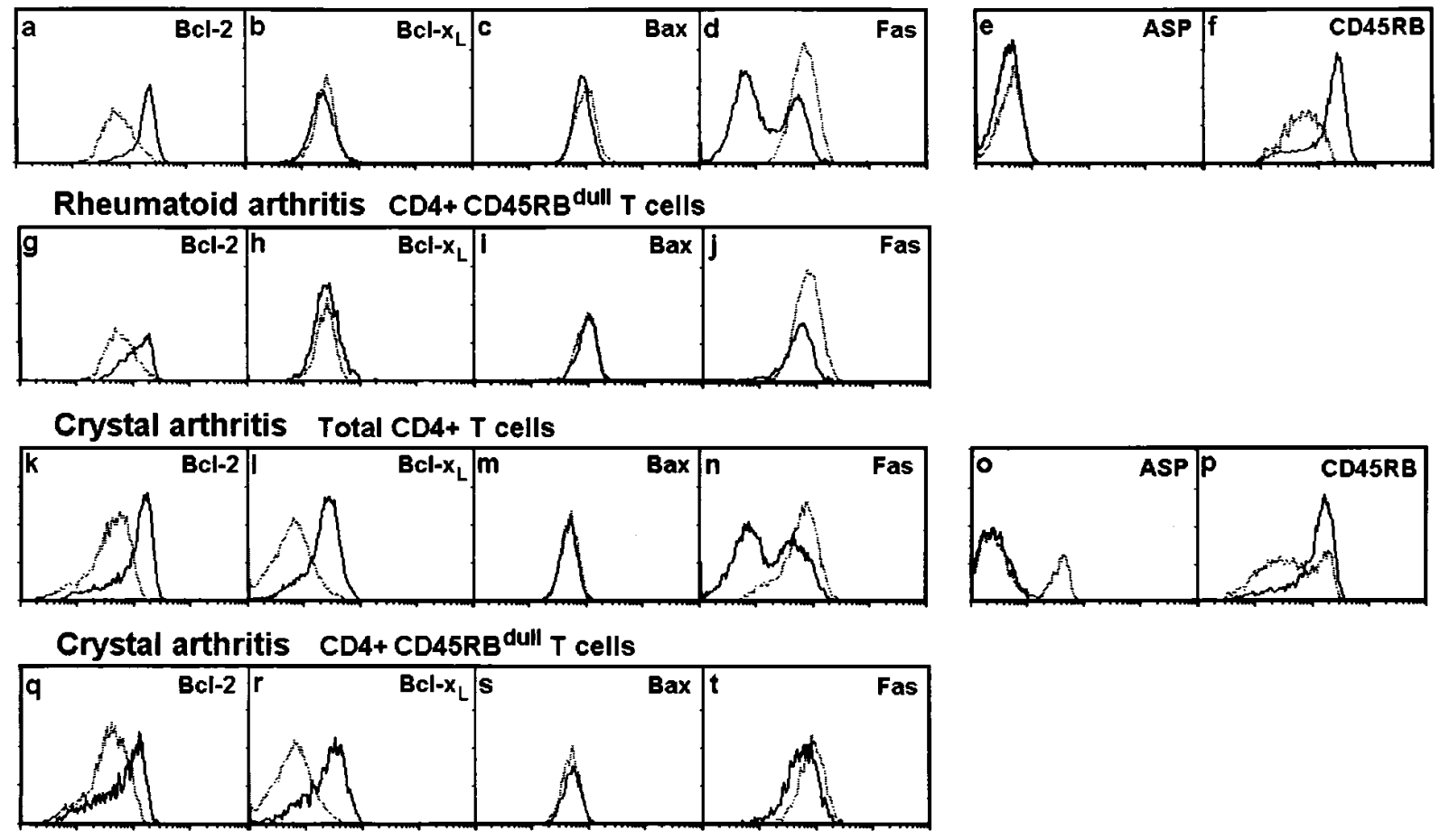

Figure 2. Expression of apoptosis-associated molecules in the peripheral blood (solid line) and synovial fluid (broken line) of a patient with RA $(a-f)$ and from a patient with acute crystal arthritis $(k-p)$. Expression of these molecules in the CD45RB ${ }^{\text {dull }}$ fractions of blood and of synovial fluid from the same patients is depicted in $g_{-j}(\mathrm{RA})$ and $q-t$ (crystal arthritis). The CD45RB dull population was defined by gating on CD45RA+ T cells as described (7). Representative of eight experiments (RA) and three experiments (crystal arthritis).

In vitro susceptibility to apoptosis of rheumatoid synovial fluid T cells. The highly differentiated phenotype of rheumatoid synovial $T$ cells together with their low expression of bcl-2 and high expression of Fas suggested that these cells should be particularly susceptible to apoptosis, but no evidence of $\mathrm{T}$ cell apoptosis could be detected in RA synovial fluids despite clear evidence of non-T cell death. We separated synovial fluid and peripheral blood $\mathrm{T}$ lymphocytes from patients with RA and subjected them to various conditions of culture. Unstimulated synovial T cells showed clear evidence of death by apoptosis in an initial series of four experiments. After $3 \mathrm{~d}, 45 \pm 5.6 \%$ (Mean \pm SD) of cells in control (untreated) rheumatoid synovial $\mathrm{T}$ cell cultures were apoptotic, while $63.5 \pm 3.5 \%$ of the original input remained viable. In cultures treated with $25 \mathrm{U} / \mathrm{ml}$ IL-2, $34.5 \pm 1.7 \%$ of cells were apoptotic and $78.5 \pm 2.6 \%$ of the original input remained viable. Clearly IL-2 induced some proliferation in synovial T cells, because the cells recovered at day 3 represent more than the original cell input. Blood $\mathrm{T}$ cells showed only $15.5 \pm 3.2 \%$ apoptosis over this period, reduced to $8.2 \pm 3.5 \%$ by addition of IL-2. Only minimal proliferation was observed with peripheral blood cells under these conditions.

$I L-2 R$ y chain cytokine-mediated rescue of rheumatoid synovial $T$ cells. Rheumatoid synovial fluid T cells were cultured for up to $12 \mathrm{~d}$ in the presence of a range of cytokines which are known to influence the survival of apoptotic cells. IL-2, IL-4, and IL-15 all use a shared receptor component known to influence $\mathrm{T}$ cell survival. IL-10 has a short-term ability to inhibit $\mathrm{T}$ cell apoptosis. PDGF and IGF-1 strongly inhibit apoptosis in many cell types (28). IL-6 was included as a control, because this molecule has been shown previously to have no effect on T cell apoptosis (13). Preliminary experiments suggested that while IL-2 and IL-15 were able to inhibit apoptosis of synovial fluid T cells, IL-15 was by far the most effective. This result was surprising, because IL-2 and IL-15 use shared $\beta$ and $\gamma$ chains, which form the complete signaling region of the molecule, only the $\alpha$ chain is different (29). This result may simply have reflected different functional concentrations, but simultaneous titration of the different cytokines (Fig. $3 a$ ) confirmed the enhanced survival-inducing effect of IL-15. Apoptosis was confirmed as the route of death in these experiments by ASP labeling (Fig. 3 b). Induction of T cell survival by these cytokines operates through upregulation of Bcl-2 expression in activated $\mathrm{T}$ cells and this effect was confirmed in synovial fluid populations (see Fig. 6). IL-4 showed a marginal but reproducible improvement in synovial T cell survival, but the remaining cytokines (IL-6, IL-10, PDGF, and IGF-1) were ineffective.

The rescue of synovial fluid $T$ cells from apoptosis by coculture with fibroblasts. Synovial fluid and peripheral blood T cells were cultured in the presence or absence of a fibroblast monolayer. For more objective comparison, peripheral blood T cells were depleted of CD45RA+ cells, which are highly resistant to apoptosis and are absent from rheumatoid synovia. Fibroblasts were obtained from either RA synovium, non-RA inflammatory synovium, or from embryonic lung. The rate of loss of cells from each of these cultures was determined over a period of $12 \mathrm{~d}$. When cultured alone, death of synovial fluid $\mathrm{T}$ cells was considerably more rapid than in parallel blood $\mathrm{T}$ cell cultures (Fig. 4). CD45RO+ T cells from blood died more rap- 


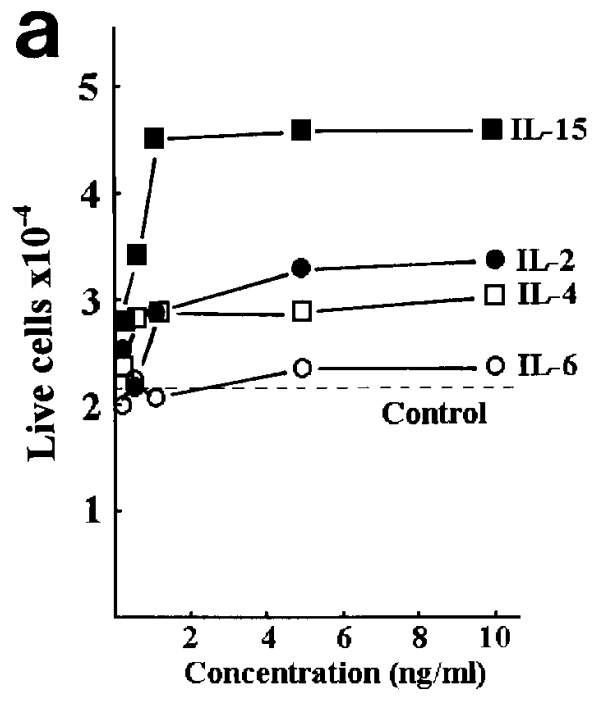

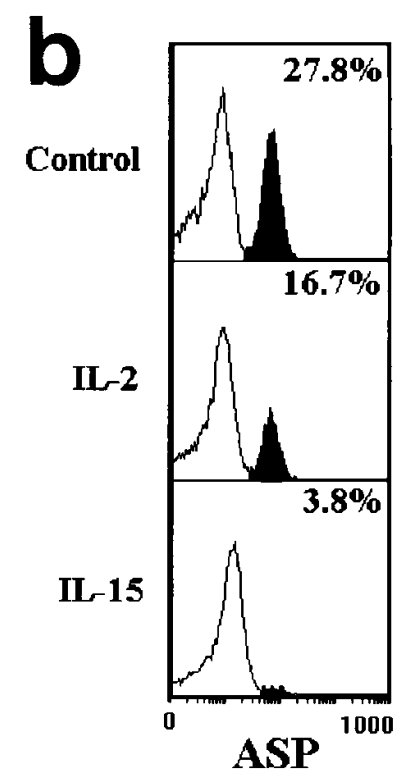

Figure 3. The effect of cytokines on rescue of synovial $\mathrm{T}$ cells from apoptosis. Synovial T cells were cultured for $3 \mathrm{~d}$ either in complete medium alone or with various concentrations of cytokines added. The number of viable cell recovered after $3 \mathrm{~d}$ is indicated in $a$ (control value represents complete medium alone). The proportion of apoptotic cells recovered at day 3 using $5 \mathrm{mM}$ cytokines is indicated in $b$. Representative of three experiments. idly than unfractionated blood T cells, but much more slowly than synovial cells. Coculture with fibroblasts induced a marked inhibition of apoptosis in synovial fluid T cells, which was also apparent to a lesser extent with blood T cells, particularly the CD45RO+ subset (Fig. 4). Direct cell contact in cocultures was not absolutely necessary, because supernatants from confluent fibroblast cultures were also quite effective, although direct coculture always induced markedly better survival. In contrast to previous reports, we found no difference in the ability of fibroblasts from various sources to enhance $\mathrm{T}$ cell survival. As IL-15 is produced by certain fibroblasts, we performed inhibition studies using a polyclonal anti-IL-15 antibody. When anti-IL-15 was added to fibroblast culture supernatants be-

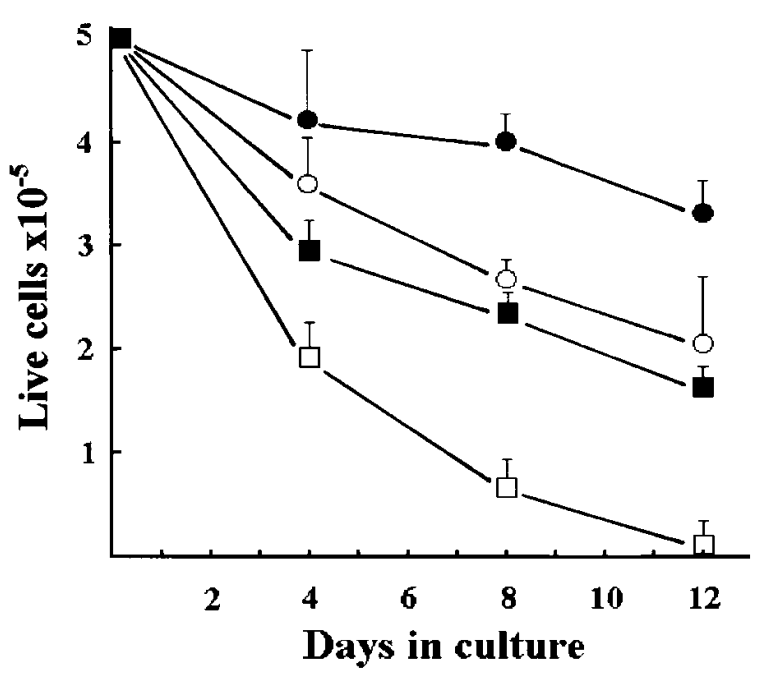

Figure 4. The influence of fibroblast coculture on survival of $\mathrm{CD} 45 \mathrm{RO}+$ blood $\mathrm{T}$ cells and synovial fluid $\mathrm{T}$ cells over $12 \mathrm{~d}$ in culture. (Open boxes) Synovial fluid T cells in complete medium alone. (Filled boxes) Synovial fluid T cells cocultured with fibroblasts. (Open circles) Peripheral blood CD45RO + T cells in medium alone. (Filled circles) Peripheral blood CD45RO+ T cells cocultured with fibroblasts. Representative of four experiments. fore incubation with synovial or peripheral blood T cells, no change in cell survival was observed compared with untreated fibroblast culture supernatant (data not shown).

In three experiments we confirmed that synovial $\mathrm{T}$ cells from patients with gout, which showed evidence of apoptosis in vivo, could also be induced to survive in vitro culture by addition of either $5 \mathrm{ng} / \mathrm{ml} \mathrm{IL-15}$ or $50 \%$ fibroblast conditioned medium (Fig. 5). Gout synovial $\mathrm{T}$ cells behaved in a similar fashion during in vitro culture to those from rheumatoid patients.

$24 \mathrm{~h}$ after initiation of cultures with fibroblast culture supernatant, synovial $\mathrm{T}$ cells from either RA or gout patients showed a phenotype $\mathrm{Bcl}-2^{\text {low }} \mathrm{Bcl}-\mathrm{x}_{\mathrm{L}}^{\text {high }}$. $\mathrm{T}$ cells cultured with

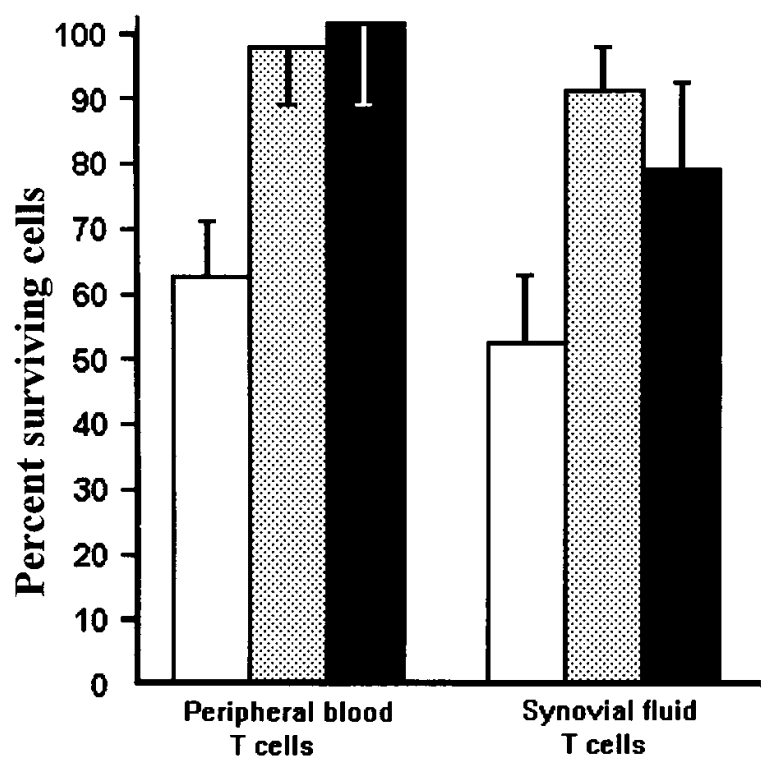

Figure 5. Peripheral blood and synovial fluid T cells from acute crystal arthritis patients were cultured for $72 \mathrm{~h}$ in medium alone (control, open bars), $5 \mathrm{mM} \mathrm{IL-15}$ (shaded bars), or $50 \%$ fibroblast conditioned medium (filled bars). The proportion of cells surviving after each regimen is indicated (three experiments). 


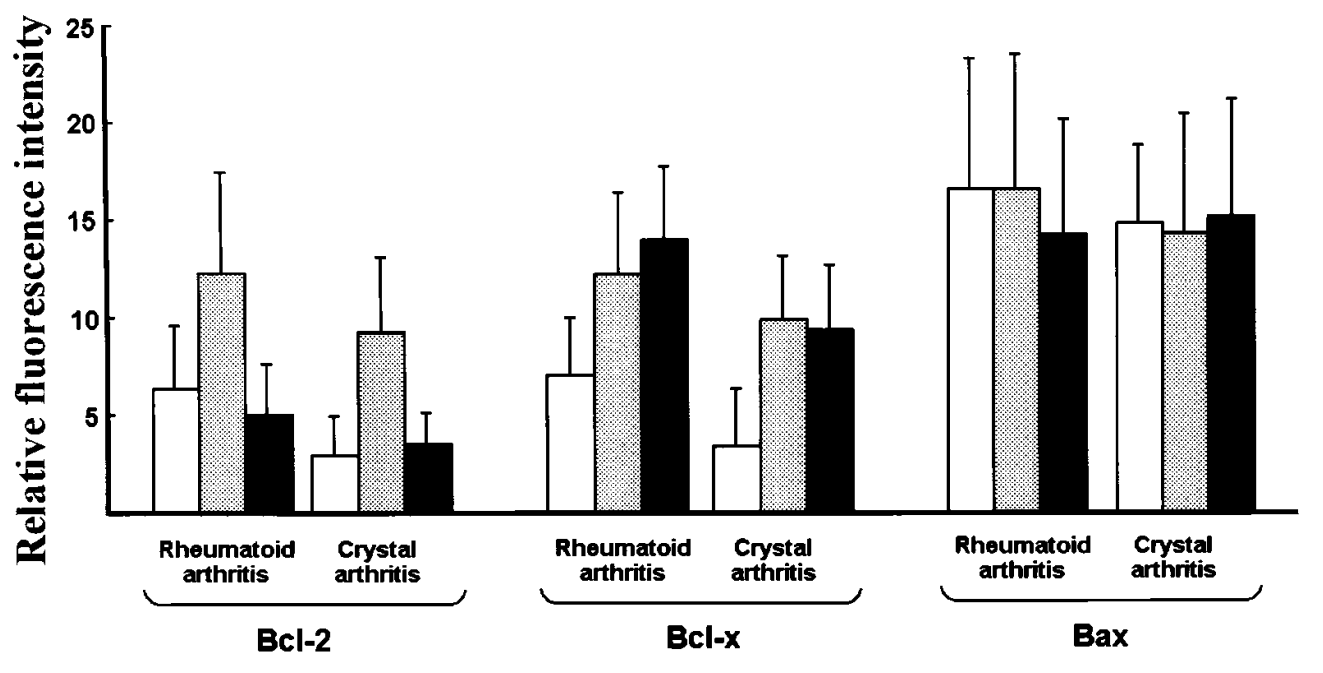

Figure 6. The effect of IL-15 and fibroblast conditioned medium on expression of apoptosis control gene products in synovial $\mathrm{T}$ cells from patients with RA or acute crystal arthritis. Note that IL-15 (shaded bars) induces a Bcl-2 $2^{\text {high }} \mathrm{Bcl}-\mathrm{x}_{\mathrm{L}}$ high phenotype, while fibroblast conditioned medium (filled bars) maintains the $\mathrm{Bcl}-2^{\text {low }} \mathrm{Bcl}-\mathrm{x}_{\mathrm{L}}$ high phenotype observed for rheumatoid synovial T cells in Fig. 2. Control cultures (open bars) leading to extensive apoptosis yield a phenotype $\mathrm{Bcl}-2^{\text {low }} \mathrm{Bcl}-$ $\mathrm{x}_{\mathrm{L}}{ }^{\text {low }}$ similar to that observed for crystal arthritis patients in Fig. 2. Values obtained after $24 \mathrm{~h}$ of culture. Mean and SD of three experiments.
IL-15 (5 ng/ml) were Bcl- $2^{\text {high }} \mathrm{Bcl}-\mathrm{x}_{\mathrm{L}}{ }^{\text {high }}$. Untreated synovial fluid $\mathrm{T}$ cells cultured for $24 \mathrm{~h}$ in medium alone were Bcl-2 $2^{\text {low }}$ Bcl- $\mathrm{x}_{\mathrm{L}}{ }^{\text {low }}$ (Fig. 6). No significant differences were observed between rheumatoid and gout patients in these experiments.

An integrin-associated mechanism of rescue of synovial fluid T cells. Synovial fluid T cells were cultured for periods of 3 and $6 \mathrm{~d}$ in medium conditioned by confluent fibroblasts. Parallel cultures were treated with either RGDS $(1 \mathrm{mM})$ peptide, which mimics the conserved RGD motif used by several integrins, or RGES (1 mM) peptide which acts as a control sequence (Fig. 7). The conditioned medium led to a significant increase in survival of synovial T cells at both time points studied. This was markedly reduced by the addition of RGDS peptide; the RGES peptide control showed no effect (Fig. 7).

Synovial fluid T cells were cultured for up to $12 \mathrm{~d}$ in the presence or absence of either $0.1-1.0 \mathrm{mg} / \mathrm{ml}$ hyaluronic acid, $1.0-50 \mu \mathrm{g} / \mathrm{ml}$ of serum, or fibroblast derived fibronectin. A partial inhibition of synovial fluid $\mathrm{T}$ cell apoptosis was observed using hyaluronic acid in low concentrations in several

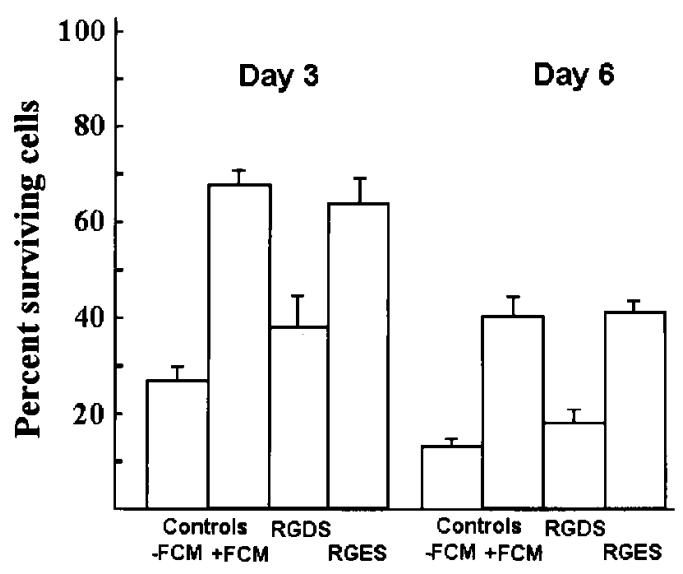

Figure 7. The influence of Arg-Gly-Asp-Ser $(R G D S)$ and Arg-GlyGlu-Ser $(R G E S)$ peptides on the rescue of synovial fluid T cells by fibroblast culture supernatants. Results indicate percent recovery of the original input of cells at days 3 and 6. Mean and SD of three experiments. assays, though this was not consistent; this molecule proved toxic to T cells at levels reported to be found in synovial fluid. Serum fibronectin had no significant effect, though fibroblastderived fibronectin again showed a partial inhibition of synovial $\mathrm{T}$ cell apoptosis in some experiments, this effect was not consistent between samples. Hyaluronic acid preadhered to culture wells showed no measurable effect on synovial $\mathrm{T}$ cell apoptosis. Hyaluronidase treatment $(20 \mathrm{U} / \mathrm{ml})$ of supernatants from synovial fibroblasts before culture with synovial fluid $\mathrm{T}$ cells did not affect fibroblast-mediated rescue of the $\mathrm{T}$ cells (not shown).

\section{Discussion}

In this study, $\mathrm{T}$ cells in rheumatoid synovial fluid were found to express a phenotype: bcl- $2^{\text {low }}$ Bax $^{\text {high }}$ Fas $^{\text {high }}$ CD45RB ${ }^{\text {dull }}$ which suggests susceptibility to apoptosis $(5,13,15,16)$. However, synovial fluid $\mathrm{T}$ cells were found to be strongly resistant to apoptosis in vivo, which is in accordance with a recent observation (30). The possibility that synovial $\mathrm{T}$ cells may represent an intrinsically stable population was excluded because removal of these cells from the synovial microenvironment led to marked spontaneous apoptosis. A further explanation for the failure to observe $\mathrm{T}$ cell apoptosis in vivo could be phagocytosis of apoptotic lymphocytes by macrophages $(31,32)$. However, Annexin V binds to exposed phosphatidylserine residues on cell membranes (33). This is a characteristic which appears early in apoptosis and is used as a structure for recognition by certain phagocytes $(31,33)$; yet this also failed to show any positive $\mathrm{T}$ cells in synovial fluid of RA patients. Furthermore, the high prevalence of apoptotic neutrophils in the synovium, which has been reported previously (34) and was also observed in this study, suggests that failure to identify apoptotic cells before phagocytosis is unlikely, because these cells are also cleared by macrophages and the recognition mechanisms are the same $(31,32)$. Perhaps the most intriguing observation in this respect was that patients with crystal arthritis consistently showed evidence of high levels of $\mathrm{T}$ cell apoptosis in vivo. This indicated that the lack of $\mathrm{T}$ cell apoptosis in rheumatoid synovium was a distinct phenomenon, related to fac- 
tors present in the rheumatoid joint and that these factors had a selective effect on T cell survival, because apoptosis of other cell types was quite marked. In this study we explored reasons for the inhibition of rheumatoid synovial $\mathrm{T}$ cell death.

Previous reports have shown that genes other than $\mathrm{Bcl}-2$ can prevent apoptosis (35). One of these, $B c l-x$, can be differentially spliced to generate large $\left(\mathrm{Bcl}-\mathrm{x}_{\mathrm{L}}\right)$ and small $\left(\mathrm{Bcl}-\mathrm{x}_{\mathrm{S}}\right)$ mRNA transcripts which code for proteins that either prevent or induce apoptosis, respectively (15). In humans, no Bcl- $\mathrm{x}_{\mathrm{S}}$ protein has been detected. Bcl- $\mathrm{x}_{\mathrm{L}}$ is the only protein observed (13). Previous reports have indicated that Bcl-2 and Bcl- $\mathrm{x}_{\mathrm{L}}$ repress a common pathway leading to apoptosis (35). We found that although $\mathrm{Bcl}-2$ expression was low in synovial T cells, Bcl- $\mathrm{x}_{\mathrm{L}}$ remained at levels comparable with those seen in peripheral blood lymphocytes from the same patients. This suggested that one reason for the lack of apoptosis in synovial $T$ cells may be maintenance of high $\mathrm{Bcl}-\mathrm{x}_{\mathrm{L}}$ expression. This observation also indicated that factors present in the synovial microenvironment could differentially regulate $\mathrm{Bcl}-\mathrm{x}_{\mathrm{L}}$ expression relative to Bcl-2. In accordance with this observation, $\mathrm{T}$ cells from gout patients who showed significant in situ apoptosis expressed low levels of both $\mathrm{Bcl}-2$ and $\mathrm{Bcl}-\mathrm{x}_{\mathrm{L}}$.

Previously, we have described two mechanisms by which apoptosis of cytokine-deprived $\mathrm{T}$ cells can be retarded. When IL-2 is withdrawn from T cells the expression of both Bcl-2 and Bcl- $\mathrm{x}_{\mathrm{L}}$, but not Bax or Fas, was reduced (13). If T cells were subsequently cultured with IL-2R $\gamma$ chain cytokines, apoptosis was prevented and $\mathrm{Bcl}-2$ and $\mathrm{Bcl}-\mathrm{x}_{\mathrm{L}}$ expression was upregulated, indicating that these cytokines coregulate the expression of these genes (13). The second mechanism for rescue involves coculture of the $\mathrm{T}$ cells with fibroblast monolayers; this system induced survival without proliferation. An important observation was that Bcl-2 expression was reduced during fibroblast-mediated rescue, but $\mathrm{Bcl}-\mathrm{x}_{\mathrm{L}}$ expression was maintained, indicating that this mechanism of survival uncouples the expression of these genes (19). Although significant quantities of IL-15 have been reported to be present in rheumatoid synovium and it appears to act as a chemotactic mediator, synovial IL-15 is not able to support T cell proliferation, suggesting that it is largely complexed to inhibitors (17). The limited $\mathrm{T}$ cell proliferation observed in situ and the low Bcl-2 expression observed suggest that IL-2R $\gamma$ chain cytokines are unlikely to be the principle mechanism preventing apoptosis of $\mathrm{T}$ cells in the rheumatoid joint. However, the low Bcl-2 but high Bcl- $\mathrm{x}_{\mathrm{L}}$ expression of the synovial $\mathrm{T}$ cells in vivo suggests that the stromal cell-mediated route of rescue is likely to operate in vivo. Culture experiments in vitro supported this possibility and showed that coculture with fibroblast conditioned medium maintained the in vivo phenotype of synovial T cells $\left(\mathrm{Bcl}-2^{\text {low }}\right.$, $\left.\mathrm{Bcl}-\mathrm{x}_{\mathrm{L}}{ }^{\text {high }}\right)$. In contrast, addition of IL-15 led to high Bcl-2 and $\mathrm{Bcl}-\mathrm{x}_{\mathrm{L}}$ expression. Indirect evidence supported the role of stromal cells in mediating synovial $\mathrm{T}$ cell survival: proliferating pannus tissue in rheumatoid joints contains a high density of fibroblasts (20). The observation that synovial T cells from patients with crystal-induced arthritis show readily detectable levels of $\mathrm{T}$ cell apoptosis is interesting in this respect since synovial thickening in such patients is usually less marked with considerably less evidence of fibroblast proliferation. Synovial $\mathrm{T}$ cells from patients with gout could also be rescued by either IL-15 or fibroblast conditioned medium. However the phenotype produced was in each case different from that of cells isolated directly from patients but similar to rheumatoid cells cul- tured in the same way. These results suggest strongly that apoptosis of $\mathrm{T}$ cells in the rheumatoid synovium is actively inhibited by stromal cells.

Many integrin molecules bind to specific ligands through a motif consisting of Arg-Gly-Asp (36). In vitro the peptide ArgGly-Asp-Ser (RGDS) can be used to inhibit such interactions, Arg-Gly-Glu-Ser (RGES) is used as a control. The ability of fibroblast conditioned medium to rescue synovial $\mathrm{T}$ cells from apoptosis was markedly inhibited by the RGDS but not the RGES peptide, suggesting that an integrin interaction is likely to be involved. Similar results were obtained using in vitro activated $\mathrm{T}$ cells derived from peripheral blood. Hyaluronic acid is present in extremely high levels in synovial fluid; intriguingly this molecule has been reported to block Fas-mediated activation-induced apoptosis in mouse T cell hybridomas (27). We observed no inhibition of spontaneous synovial $\mathrm{T}$ cell apoptosis by hyaluronic acid over a wide range of concentrations. However, this does not exclude an active role for hyaluronate in modulating activation-induced apoptosis in situ, as the Fasderived signals generated are likely to be transient and not persist in culture (35).

These data show that the highly differentiated and apparently unstable state of $\mathrm{T}$ lymphocytes in chronically inflamed joints may result in part from active inhibition of $\mathrm{T}$ cell apoptosis by environmental factors associated with the inflammation itself. The apparently nonfunctional nature of synovial fluid IL-15 (17) and the phenotype of T cells immediately after isolation from the joint of rheumatoid patients ( $\left.\mathrm{Bcl}-2^{\text {low }}, \mathrm{Bcl}-\mathrm{x}^{\text {high }}\right)$ strongly favors stromal interactions as the dominant mechanism for maintenance of persistent $\mathrm{T}$ cell infiltration in RA. Our observations suggest that the $\mathrm{T}$ cell infiltrates in chronically inflamed rheumatoid synovia arise and persist not only as a result of recruitment $(17,37)$ but also because these cells are actively prevented from dying by the abnormal synovial microenvironment, a mechanism which is apparently inoperative in the joints of patients with acute crystal arthritis. Thus, resolution of inflammation in joints may be promoted most effectively by targeting the pannus fibroblasts rather than the $\mathrm{T}$ cells themselves.

\section{Acknowledgments}

We would like to thank Drs. C. Gordon, G.D. Kitas, M. Pugh, and M.E. Allen for providing clinical material.

This work was funded by the Arthritis and Rheumatism Council UK (SO190, SO130, SO185, HO156) and the Medical Research Council (G9218555MA, G931916MA).

\section{References}

1. Salmon, M., and J.S.H. Gaston. 1995. The role of T-lymphocytes in rheumatoid-arthritis. Br. Med. Bull. 51:332-345.

2. Akbar, A.N., L. Terry, A. Timms, P.C.L. Beverley, and G. Janossy. 1988. Loss of CD45R and gain of UCHL1 reactivity is a feature of primed T cells. $J$. Immunol. 140:2171-2178.

3. Sanders, M.E., M.W. Makgoba, S.O. Sharrow, D. Stephany, T.A Springer, H.A. Young, and S. Shaw. 1988. Human memory T lymphocytes express increased levels of 3 cell adhesion molecules (LFA-3, CD2, and LFA-1) and 3 other molecules (UCHL1, CDw29, and Pgp-1) and have enhanced IFN- $\gamma$ production. J. Immunol. 140:1401-1407.

4. Salmon, M., G.D. Kitas, and P.A. Bacon. 1989. Production of lymphokine mRNA by CD45R + and CD45R - helper T cells from human peripheralblood and by human CD4+ T cell clones. J. Immunol. 143:907-912.

5. Salmon, M., D. Pilling, N.J. Borthwick, N. Viner, G. Janossy, P.A. Bacon, and A.N. Akbar. 1994. The progressive differentiation of primed T cells is asso- 
ciated with an increasing susceptibility to apoptosis. Eur. J. Immunol. 24:892899.

6. Mason, D., and F. Powrie. 1990. Memory CD4+ T cells in man form 2 distinct subpopulations, defined by their expression of isoforms of the leukocyte common antigen, CD45. Immunology. 70:427-433.

7. Matthews, N., P. Emery, D. Pilling, A. Akbar, and M. Salmon. 1993. Subpopulations of primed T helper cells in rheumatoid arthritis. Arthritis Rheum. 36:603-607.

8. Thomas, R., M. Mcilraith, L.S. Davis, and P.E. Lipsky. 1992. Rheumatoid synovium is enriched in CD45RB ${ }^{\text {dim }}$ mature memory T-cells that are potent helpers for B-cell differentiation. Arthritis Rheum. 35:1455-1465.

9. Cohen, J.J., R.C. Duke, V.A. Fadok, and K.S. Sellins. 1992. Apoptosis and programmed cell-death in immunity. Ann. Rev. Immunol. 10:267-293.

10. Akbar, A.N., N. Borthwick, M. Salmon, W. Gombert, M. Bofill, N. Shamsadeen, D. Pilling, S. Pett, J.E. Grundy, and G. Janossy. 1993. The significance of low bcl-2 expression by CD45RO T cells in normal individuals and patients with acute viral infections. The role of apoptosis in T cell memory. J. Exp. Med. 178:427-438.

11. Dhein, J., H. Walczak, C. Baumler, K.M. Debatin, and P.H. Krammer. 1995. Autocrine T cell suicide mediated by Apo-1/(Fas/CD95). Nature (Lond.). 373:438-441.

12. Brunner, T., R.J. Mogil, D. Laface, N.J. Yoo, A. Mahboubi, F. Echeverri, S.J. Martin, W.R. Force, D.H. Lynch, C.F. Ware, and D.R. Green. 1995. Cell-autonomous fas (cd95) fas-ligand interaction mediates activation-induced apoptosis in t-cell hybridomas. Nature (Lond.). 373:441-444.

13. Akbar, A.N., N. Borthwick, R.G. Wickremasinghe, P. Panayiotidis, D. Pilling, M. Bofill, S. Krajewski, J.C. Reed, and M. Salmon. 1996. Interleukin-2 receptor common $\gamma$-chain cytokines regulate activated $\mathrm{T}$ cell apoptosis in response to growth factor withdrawal: selective induction of anti-apoptotic (bcl-2, bcl- $\mathrm{x}_{\mathrm{l}}$ ) but not pro-apoptotic (bax, bcl- $\mathrm{x}_{\mathrm{s}}$ ) gene expression. Eur. J. Immunol. 26: 294-299.

14. Grabstein, K.H., J. Eisenman, K. Shanebeck, C. Rauch, S. Srinivasan, V. Fung, C. Beers, J. Richardson, M.A. Schoenborn, M. Ahdieh, et al. 1994. Cloning of a T-cell growth-factor that interacts with the beta-chain of the interleukin-2 receptor. Science (Wash. DC). 264:965-968.

15. Boise, L.H., M. Gonzalezgarcia, C.E. Postema, L.Y. Ding, T. Lindsten, L.A. Turka, X.H. Mao, G. Nunez, and C.B. Thompson. 1993. Bcl-x, a Bcl-2-related gene that functions as a dominant regulator of apoptotic cell-death. Cell. 74: 597-608.

16. Oltvai, Z.N., C.L. Milliman, and S.J. Korsmeyer. 1993. Bcl-2 heterodimerizes in-vivo with a conserved homolog, bax, that accelerates programmed cell death. Cell. 74:609-619.

17. McInnes, I.B., J. Al-Mughales, M. Field, B.P. Leung, F.P. Huang, R. Dixon, R.D. Sturrock, P.C. Wilkinson, and F.Y. Liew. 1996. The role of interleukin-15 in T-cell migration and activation in rheumatoid arthritis. Nat. Med. 2: $175-182$.

18. Scott, S., F. Pandolfi, and J.T. Kurnick. 1990. Fibroblasts mediate T cell survival. A proposed mechanism for retention of primed T cells. J. Exp. Med. 172:1873-1876.

19. Gombert, W., D.L. Wallace, N.J. Borthwick, H. Hyde, D. Pilling, M. Bofill, P.C.L. Beverley, G. Janossy, M. Salmon, and A.N. Akbar. 1996. Phenotypic changes and reactivation characteristics of CD4+ T cells after fibroblast mediated rescue from apoptosis. Immunology. 89:397-404.

20. Fassbender, H.G. 1975. Pathology of Rheumatic Diseases. SpringerVerlag Inc., New York.
21. Arnett, F.C., S.M. Edworthy, D.A. Bloch, D.J. Mcshane, J.F. Fries, N.S. Cooper, L.A. Healey, S.R. Kaplan, M.H. Liang, H.S. Luthra, et al. 1998. The American Rheumatism Association 1987 revised criteria for the classification of rheumatoid-arthritis. Arthritis Rheum. 31:315-324.

22. Pilling, D., G.D. Kitas, M. Salmon, and P.A. Bacon. 1989. The kinetics of interaction between lymphocytes and magnetic polymer particles. J. Immunol. Meth. 122:235-241.

23. Grand, R.J.A., A.E. Milner, T. Mustoe, G.D. Johnson, D. Owen, M.L. Grant, and C.D. Gregory. 1995. A novel protein expressed in mammalian cells undergoing apoptosis. Exp. Cell Res. 218:439-451.

24. Smith, C.A., G.T. Williams, R. Kingston, E.J. Jenkinson, and J.J.T. Owen. 1989. Antibodies to CD3/T cell receptor complex induce death by apoptosis in immature T cells in thymic cultures. Nature (Lond.). 337:181-184.

25. Darzynkiewicz, Z., X. Li, and J.P. Gong. 1994. Assays of cell viability: discrimination of cells dying by apoptosis. Methods Cell Biol. 41:15-38.

26. Vermes, I., C. Haanen, H. Steffensnakken, and C. Reutelingsperger. 1995. A novel assay for apoptosis: flow cytometric detection of phosphatidylserine expression on early apoptotic cells using fluorescein-labeled AnnexinV. J. Immunol. Meth. 184:39-51.

27. Ayroldi, E., L. Cannarile, G. Migliorati, A. Bartoli, I. Nicoletti, and C. Riccardi. 1995. CD44 (Pgp-1) inhibits CD3 and dexamethasone-induced apoptosis. Blood. 86:2672-2678.

28. Raff, M.C., B.A. Barres, J.F. Burne, H.S. Coles, Y. Ishizaki, and M.D Jacobson. 1993. Programmed cell-death and the control of cell-survival: lessons from the nervous-system. Science (Wash. DC). 262:695-700.

29. Giri, J.G., M. Ahdieh, J. Eisenman, K. Shanebeck, K. Grabstein, S. Kumaki, A. Namen, L.S. Park, D. Cosman, and D. Anderson. 1994. Utilization of the beta-chain and gamma-chain of the IL-2 receptor by the novel cytokineIL-15. EMBO (Eur. Mol. Biol. Organ.) J. 13:2822-2830.

30. Firestein, G.S., M. Yeo, and N.J. Zvaifler. 1995. Apoptosis in rheumatoid-arthritis synovium. J. Clin. Invest. 96:1631-1638.

31. Savill, J., V. Fadok, P. Henson, and C. Haslett. 1993. Phagocyte recognition of cells undergoing apoptosis. Immunol. Today. 14:131-136.

32. Akbar, A. N., J. Savill, W. Gombert, M. Bofill, N.J. Borthwick, F. Whitelaw, J. Grundy, G. Janossy, and M. Salmon. 1994. The specific recognition by macrophages of $\mathrm{CD} 8+\mathrm{CD} 45 \mathrm{RO}+\mathrm{T}$ cells undergoing apoptosis: a mechanism for T cell clearance during resolution of viral infections. J. Exp. Med. 180:19431947

33. Martin, S.J., C.P.M. Reutelingsperger, A.J. Mcgahon, J.A. Rader, R.C.A.A. Vanschie, D.M. Laface, and D.R. Green. 1995. Early redistribution of plasma-membrane phosphatidylserine is a general feature of apoptosis regardless of the initiating stimulus: inhibition by overexpression of Bcl-2 and Abl. J. Exp. Med. 182:1545-1556.

34. Jones, S.T.M., J. Denton, P.J.L. Holt, and A.J. Freemont. 1993. Possible clearance of effete polymorphonuclear leukocytes from synovial-fluid by cytophagocytic mononuclear-cells: implications for pathogenesis chronicity in inflammatory arthritis. Ann. Rheum. Dis. 52:121-126.

35. Hale, A.J., C.A. Smith, L.C. Sutherland, V.E.A. Stoneman, V.L. Longthorne, A.C. Culhane, and G.T. Williams. 1996. Apoptosis: molecular regulation of cell-death. Eur. J. Biochem. 236:1-26.

36. Stewart, M., M. Thiel, and N. Hogg. 1995. Leukocyte integrins. Curr. Opin. Cell Biol. 7:690-696.

37. Iannone, F., V.M. Corrigall, G.H. Kingsley, and G.S. Panayi. 1994. Evidence for the continuous recruitment and activation of $T$ cells into the joints of patients with rheumatoid arthritis. Eur. J. Immunol. 24:2706-2713. 